\title{
Hymenopterous parasitoids attacking Acanthiophilus helianthi Rossi (Diptera: Tephritidae) pupae in Kohgiluyeh Safflower farms of Iran
}

\author{
K. Saeidi, ${ }^{1}$ S. Mirfakhraie, ${ }^{2}$ F. Mehrkhou ${ }^{2}$ \\ ${ }^{1}$ Department of Plant Protection, Agricultural and Natural Resources Research and Education \\ Center, Kohgiluyeh va Boyerahmad, Province, Yasouj; ${ }^{2}$ Department of Plant Protection, College of \\ Agriculture, Urmia University, Urmia, Iran
}

\begin{abstract}
The Safflower capsule fly (SCF), Acanthiophilus helianthi Rossi (Diptera: Tephritidae) is the most destructive insect pest attacking the Safflower Carthamus tinctorius L. plant which are cultivated as an oil crop. It is mainly controlled through application of broad-spectrum insecticides, which can adversely affect safflower farms ecosystem and consequently human health. Since a first step in setting up an integrated pest management program is to assess the biological control agents within the ecosystem. Therefore, in this research work the pupal parasitoids of Safflower capsule fly a main insect pest attacking Safflower plants were identified. The impact of these parasitoids against this pest was evaluated on the varying pest generations and within different locations in Kohgiluyeh province during 2008-2009 seasons. Pupal parasitoid adults of SCF were recorded from fieldreared pupae, which had been collected from heavily infested small flower heads of the first generation as well from large flower heads of the second and third generations. Rate of parasitism on A. helianthi pupae was estimated as the number of parasitoids over the total count of parasitoids and flies. Ten hymenopterous species belonging to different families parasitizing insect pupae were screened as follows: Bracon hebetor (Spinola, 1808) and Bracon luteator (Spinola, 1808) (Braconidae); Isocolus tinctorious (Melika and Gharaei, 2006)
\end{abstract}

Correspondence: Karim Saeidi, Department of Plant Protection, Agricultural and Natural Resources Research and Education Center, Kohgiluyeh va Boyerahmad Province, P.0. Box 351, Yasouj, Iran.

Tel.: +98.741.3334821/+98.741.3334821 - Fax: +98.741.3334011.

E-mail: saeidi391@yahoo.com

Key words: Biological control; Kohgiluyeh; pupal parasitoids; Safflower capsule fly.

Received for publication: 4 February 2015.

Revision received: 4 April 2016.

Accepted for publication: 4 April 2016.

(C) Copyright K. Saeidi et al., 2016

Licensee PAGEPress, Italy

Journal of Entomological and Acarological Research 2016; $48: 5085$

doi:10.4081/jear.2016.5085

This article is distributed under the terms of the Creative Commons Attribution Noncommercial License (by-nc 4.0) which permits any noncommercial use, distribution, and reproduction in any medium, provided the original author(s) and source are credited.
(Cynipidae); Pronotalia carlinarum (Szelenyi and Erdos, 1951) (Eulophidae); Eurytoma acroptilae (Zerova, 1986) (Eurytomidae); Ormyrus orientalis (Walker, 1871) (Ormyridae); Colotrechnus viridis (Masi, 1921) and Pteromalus sp. (Walker, 1976) (Pteromalidae); and Antistrophoplex conthurnatus (Zerova, 2000) and Microdontomenus annulatus (Masi, 1899) (Torymidae). The average parasitization rate was $23 \pm 1$ as revealed through the present study. The highest parasitization rate occurred during the first generation in all localities tested, as well as in years. Statistical analysis revealed that there were significant differences between parasitization rates by pupal parasitoids within various host generations and localities.

\section{Introduction}

There are more than 400 ha of Safflower farms in Kohgiluyeh province, Iran cultivated with the Safflower Carthamus tinctorius L. plants, which are used for production of oil (Agyeman et al., 2002; Alizadeh et al., 2008; Emongor, 2010). Safflower capsule fly (SCF), Acanthiophilus helianthi Rossi (Diptera: Tephritidae) has been reported from many parts of the world including Ethiopia (Bezzi, 1924); Rumania (Manolache, 1940); India (Bhatia and Singh, 1939; Pruthi, 1941); Pakistan (Din and Ghani, 1963); Palestine (Avidov and Kolter, 1966); Turkey (Giray, 1966); Hungary (Martinovich, 1966); Iraq (Al-Ali et al., 1977) and Italy (Ricci \& Ciriciofolo,1983). In Egypt it is reported by Swailem (1973) in Giza region and Hegazi et al. (1982) at Nobaria district infesting the safflower Carthamus tinctorius $\mathrm{L}$. where it is grown as an oil crop. The insect considered as a key pest of safflower in all safflower growing parts of Iran as well (Gharaei \& Joozian, 2001; Bagheri, 2006; Keyhanian, 2007; Sabzalian et al., 2010 .

The pest causes direct damage to seeds inside flower heads and indirect damage by favoring the growth of sooty mold fungi as Botrytis cinerea (Jakhmola \& Yadav, 1980; Majidi et al., 2011). During the first generation, each larva feeds on the inner side of the plant bracts and buds, but the second and third generation larvae attack to the flower ovaries, where they feed on their contents. In this way, the developing embryos are deprived from nutrition necessary for their normal growth. Thus, they shrinkened and became small in size. As a result, the larvae may feed on the embryos when they are still young and soft (Campobassa et al., 1999; Hegazi \& Moursi, 1983; Kapoor, 2005; Vaishampayan \& Kapoor, 1970; Verma et al., 1974; Zandigiacomo \& Iob, 1992).

SCF larvae complete their development in three instars, and the total developmental time from egg hatching to pupation is about 3-4 weeks under spring climatic conditions (Hegazi and Moursi, 1983). There are three generations to the pest per year and all the three are controlled by use of effective pesticides mainly belonging to organophosphate group. Biological control is a possible future strategy 
against $A$. helianthi (Avidov and Kolter, 1966). Among the biological control agents of this pest, the egg parasitoids extensively used for mass rearing and releasing programs (Bhadauria et al., 1999). Several larval or pupal parasitoids may naturally control the population of $A$. helianthi in African and Asian safflower farms (Hegazi \& Moursi, 1983; Talpur et al., 1995; Gharaei \& Joozian, 2001; Bagheri, 2006; Keyhanian, 2007; Sabzalian et al., 2010), however few studies have evaluated their role in controlling safflower capsule fly (Hegazi \& Moursi, 1983). There are few reports regarding the occurrence of safflower capsule fly parasitoids from Iran. Bagheri (2006) has reported 20-25\% mortality of $A$. helianthi pupae by an Ichnemonid wasp in Isfahan Province. Gharaei and Joozian (2001) found that the bracond wasp, Bracon hebetor parasitizing the Safflower capsule fly pupae in Ilam and Shirvan regions of Iran. Due to the problems of the hyper use of chemical pesticides in controlling this pest, it is fundamental that the first step in setting up an integrated pest management program for this pest to explore the biological control agents within an ecosystem. Therefore, in the present study, the parasitoid complex species attacking pupae of Safflower capsule fly, A. helianthi, on Safflower crops and their impact were determined within various host insect generations and host plant cultivated regions of Kohgiluyeh.

\section{Materials and methods}

Flower heads of safflower were collected from unsprayed fields to survey the pupal parasitoids of the pest during 2008-2009.

These samples were collected from five main safflower-growing sites of Kohgiluyeh including Basht $(60 \mathrm{~km}$ to north from the Gachsaran city), Bostan (40 km toward the south from the Gachsaran city), Imam Zadeh Jafar (20 km toward the East from the Gachsarn city), Gachsaran and Lishter (40 km toward the west from the Gachsaran city). In all these selected farms, Safflower seeds were planted according to the traditional procedures, but without using insecticide, herbicides, and fungicides applications.

Safflower cv. Padideh, as the prevalently grown cultivar, was taken for sampling. For the first insect generation, fifty flower heads were randomly collected from different safflower farms at the five sites in 1015 day intervals from flight peaks, which were determined from vertical yellow sticky traps. In the laboratory, each flower head was opened, and the pupae were transferred (each fifty) to a glass chimney $(10 \times 14.5$ $\mathrm{cm}$ ) covered with muslin cloth. The experiment on each container was replicated five times. Pupae of the second and third generations of $A$. helianthi, which successfully penetrated the flower heads, were randomly collected by incising the damaged flower heads. In each sample, a minimum $(n=50)$ and maximum $(n=100)$ numbers of pupae were collected. The pupae in each sample were nursed using florescence or flower heads (depending upon the generation of the pest) in separate rearing containers at room conditions of $26 \pm 2^{\circ} \mathrm{C} 65 \pm 5$ relative humidity, and 16:8 L:D a photoperiod. They were checked daily for emergence of flies and parasitoids. Following a completion of the emergence of the flies and parasitoids, percent parasitation of $A$. helianthi pupae was estimated as the number of parasitoids over the total count of parasitoids and flies. Emerged parasitoids were counted and then separated into orders and families. They were identified by Agricultural Research Center of Tabriz and Iranian Research Institute of Plant Protection Tehran, Iran. In order to compare mean of parasitism rates among generations and locations, Mstat C software (version 13; Michigan University, Ann Arbor, MI, USA) was used after transforming the means in to $\operatorname{Arcsin} \sqrt{ } \mathrm{X} / 100$.

\section{Results}

\section{The identified parasitoids species}

Ten hymenopterous parasitoids of $A$. helianthi pupae were recorded from Kohgiloyeh Safflower farms (Table 1). They belong to seven families as presented in Table 2. All parasitoid species were recorded for the first time from Safflower fly pupae at Kohgiloyeh province, Iran (Figure 1).

The average rate of braconid, cynipid, eulophid, eurytomid, ormyrid, pteromalid, and torymid parasitoids reared from $A$. helianthi pupae were $0.459 \pm 0.2,0.176 \pm 0.3,0.124 \pm 0.2,0.08 \pm 0.1,0.429 \pm 0.4,0.571 \pm 0.3$ and

Table 1. Seasonal and relative abundance of parasitoid species reared from $A$. helianthi pupae in Kohgiluyeh safflower farms during 2008 and 2009 seasons.

\begin{tabular}{|c|c|c|c|c|c|}
\hline Family species & $\begin{array}{c}\text { Total pa } \\
2008\end{array}$ & $\begin{array}{l}\text { ion rate } \\
2009\end{array}$ & $\begin{array}{l}\text { Means of total } \\
\text { Parasitization rate }\end{array}$ & $\begin{array}{c}\text { Rate of emerged } \\
\text { adults }\end{array}$ & $\begin{array}{l}\text { Emerged } \\
\text { generation }\end{array}$ \\
\hline $\begin{array}{l}\text { Torymidae } \\
\text { Antistrophoples conthurnatus } \\
\text { Microdontomenus annulatus }\end{array}$ & $\begin{array}{l}44.20 \\
61.94 \\
38.06\end{array}$ & $\begin{array}{l}47.52 \\
42.00 \\
57.99\end{array}$ & $\begin{array}{l}45.86 \\
51.97 \\
48.03\end{array}$ & $\begin{array}{c}- \\
38.06 \\
7.80\end{array}$ & $\begin{array}{c}- \\
1,2,3 \\
1,2,3\end{array}$ \\
\hline $\begin{array}{l}\text { Braconidae } \\
\text { Bracon hebetor } \\
\text { *Bracon luteator }\end{array}$ & $\begin{array}{c}17.41 \\
90.94 \\
9.06\end{array}$ & $\begin{array}{c}17.83 \\
9.47 \\
90.53\end{array}$ & $\begin{array}{l}17.62 \\
50.20 \\
49.80\end{array}$ & $\begin{array}{c}- \\
9.04 \\
8.58\end{array}$ & $\begin{array}{c}- \\
1,2,3 \\
1,2,3\end{array}$ \\
\hline $\begin{array}{l}\text { Pteromalidae } \\
\text { Colotrechnus viridis } \\
\text { *Pteromalus sp. }\end{array}$ & $\begin{array}{l}13.17 \\
91.18 \\
8.82\end{array}$ & $\begin{array}{c}11.58 \\
7.17 \\
92.83\end{array}$ & $\begin{array}{l}12.37 \\
49.18 \\
50.82\end{array}$ & $\begin{array}{l}- \\
8.82 \\
3.56\end{array}$ & $\begin{array}{c}- \\
1,2,3 \\
1\end{array}$ \\
\hline $\begin{array}{l}\text { Eurytomidae } \\
\text { Eurytoma acroptilae }\end{array}$ & $\begin{array}{l}9.60 \\
100\end{array}$ & $\begin{array}{l}6.43 \\
100\end{array}$ & $\begin{array}{l}8.02 \\
100\end{array}$ & 8.02 & - \\
\hline $\begin{array}{l}\text { Eulophidae } \\
\text { Pronotalia carlinarum }\end{array}$ & $\begin{array}{l}3.91 \\
100\end{array}$ & $\begin{array}{l}4.69 \\
100\end{array}$ & $\begin{array}{l}4.30 \\
100\end{array}$ & $\begin{array}{c}- \\
4.30\end{array}$ & $1, \overline{-}, 3$ \\
\hline $\begin{array}{l}\text { Ormyridae } \\
\text { Ormyrus orientalis }\end{array}$ & $\begin{array}{l}5.92 \\
100\end{array}$ & $\begin{array}{l}5.51 \\
100 \\
\end{array}$ & $\begin{array}{l}5.71 \\
100 \\
\end{array}$ & 5.71 & - \\
\hline $\begin{array}{l}\text { Cynipidae } \\
\text { Isocolus tinctorius }\end{array}$ & $\begin{array}{l}5.80 \\
100\end{array}$ & $\begin{array}{l}6.43 \\
100\end{array}$ & $\begin{array}{l}6.12 \\
100\end{array}$ & $\begin{array}{c}- \\
6.12\end{array}$ & $\begin{array}{c}- \\
1,2,3\end{array}$ \\
\hline
\end{tabular}

*Genus or species, as new records for Iran's insect fauna. 
$0.612 \pm 0.2$ respectively. During the three years of study, the Torymid Antistrophoplex conthurnatus, was the predominant wasp, forming $38.058 \%$ of the emerged parasitoid from A. helianthi pupae. It was the prevalent species, with its parasitic activity remarkably considerable during all the three-generation periods of the pest. The parasitoid wasp Microdontomerus annulatus represented the majority (48.027\%) of the torymid parasitoid, whereas it represented a $7.799 \%$ of the total parasitoid species received, This parasitoid could be considered one of the most important biological control agents of Safflower fly.

Bracon hebetor, forming $50.203 \%$ of the Braconids and $9.040 \%$ of the total parasitoids, was considered as an important agent with regard to its activity during the growing season and on all three generations of $A$. helianthi. The parasitoids wasp Bracon luteator forming $49.797 \%$ of the Braconids and $8.579 \%$ of the total parasitoids was considered one of the most important agents biological control safflower fly. The Cynipid Isocolus tinctorious was species, which constituted $11 \%$ of the parasitoid abundancy. It was recorded only from the first generation larvae of the pest. The remaining parasitoids occurred in relatively low numbers and did not play much $\mathrm{n}$ important role as biological control agents.

\section{Parasitization rate}

The parasitism rates on A. helianthi pupae, for three host generations, at different locations of Kohgiluyeh province during the two successive years (2008 and 2009) are shown in Figures 2 and 3.

The mean total parasitism rate of $A$. helianthi pupae in all the studied regions of Kohgiluyeh during 2008-2009 was 44.085\%. In 2008, the parasitism rate at different localities of Kohgiluyeh varied from a minimum of $36.44 \%$ up to a maximum of $43.11 \%$ with a mean of $39.77 \%$. In
2009 , it varied from a minimum of $42 \%$ up to a maximum of $53.17 \%$ with a mean of $47.58 \%$.

The results reveal that there are significant differences in pupal parasitism rates between locations, generations, and years of study. As shown in Table 3, the significantly higher pupal parasitism was occurred in Gachsaran (16.8\%), Further, there were significant differences in pupal parasitism rates between host generations with the highest rate recorded during the first generation (Table 4).

\section{Discussion}

In Kohgiluyeh, A. helianthi fulfills three generations per year. Antistrophoples conthurnatus was found to be the most common parasitoid of $A$. helianthi with a 38.058 percent of total pupal parasitism. This occurred in all the studied regions and for all the three generations. There are no evidences of parasitization with this Torymid wasp on A. helianthi pupae are reported in Iran, although Keyhanian (2007) have reported the parasitation of Safflower Capsule Fly pupae by A. conthurnatus in Qom region of Iran.

\section{Conclusions}

In the current study, $B$. hebetor recorded as a new parasitoid of $A$. helianthi with parasitization rate of $9.04 \%$. Although this wasp known as a parasitoid of codling moth, Cydia pomonella L. larvae in Iran (Radjabi, 1986), it started to use A. helianthi as a new host. This may

Table 2. Analysis of variance.

\begin{tabular}{|c|c|c|c|}
\hline Value source & Degree of freedom & Sum of squares & Probability \\
\hline Year & 1 & 0.943 & 0.0368 \\
\hline Location (L) & P & 15.433 & 0.0001 \\
\hline Generation (G) & 2 & 7.242 & 0.0061 \\
\hline $\mathrm{L} \times \mathrm{G}$ & 8 & 6.410 & \\
\hline Error & 14 & 7.263 & \\
\hline Total & 29 & 37.291 & \\
\hline
\end{tabular}

Coefficient of variation: $15.8 \%$.

Table 3. Mean (\%) of pupal parasitism at different locations during 2008-2009, Kohgiluyeh safflower farms.

\begin{tabular}{lccccc} 
Location & Basht & Bostan & Imam Zadeh Jafar & Gachsaran \\
Mean (\%) of parasitism & $12.7^{\mathrm{b}}$ & $13.6^{\mathrm{ab}}$ & $7.6^{\mathrm{c}}$ & $16.8^{\mathrm{a}}$ & $12.2^{\mathrm{b}}$ \\
\hline
\end{tabular}

Means followed by the same letter within a row are not significantly different at $\mathrm{P}<0.05$.

Table 4. Mean (\%) of pupal parasitism at different generations during 2008-2009, Kohgiloyeh safflower farms.

\begin{tabular}{lcc} 
Generation & First & Second \\
Mean (\%) of parasitism & $14.8^{\mathrm{a}}$ & $12.7^{\mathrm{b}}$ \\
\hline
\end{tabular}

Means followed by the same letter within a row are not significantly different at $\mathrm{P}<0.05$. 



Figure 1. Hymenopterous parasitoids attacking safflower fly pupae. A) Bracon luteator (Spinola, 1808); B) Eurytoma acroptilae (Zerova, 1986); C) Isocolus tinctorius (Melika and Gharaei, 2006); D) Ormyrus orientalis (Walker, 1871); E) Microdontomerus annulatus (Masi, 1899); F) Pronotalia carlinarum (Szelenyi and Erdos, 1951); G) Pteromalus sp; H) Colotrechnus viridis (Masi, 1921). 


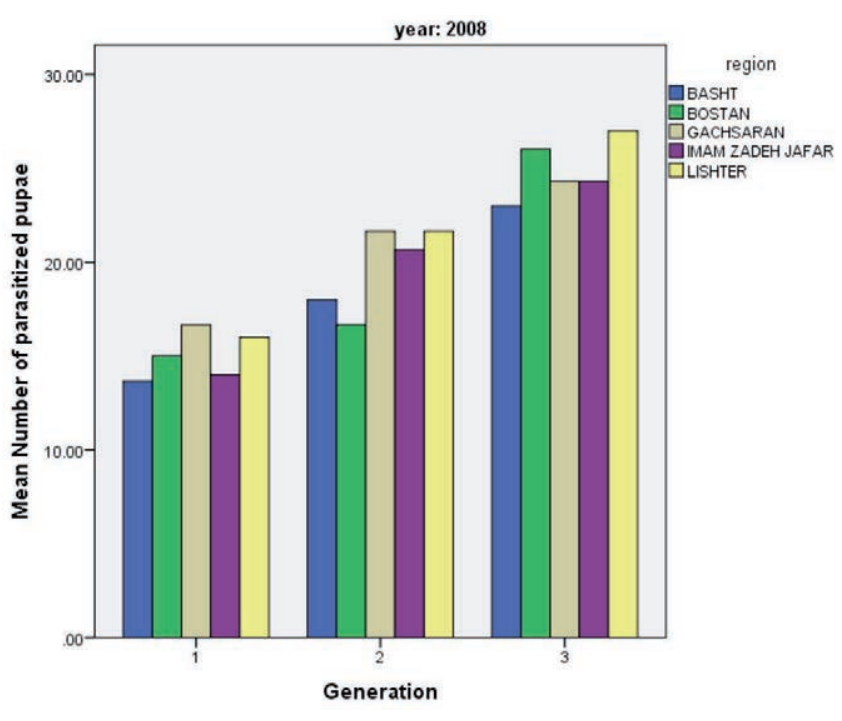

Figure 2. Percentage of parasitized pupae of Acanthiophilus helianthi in Kohgiluyeh safflower farms (2008).

be a manner to survive during the absent of its usual host. The Braconid wasp Bracon luteator (Spinola, 1808) was found in low densities in Kohgiloyeh Safflower farms. It may not have a major role in biological control, but it is mentioned as a new species for Iranian insect fauna from Kohgiluyeh.

\section{References}

AGYEMAN G.A., LOILAND J., KAROW R., HANG A.N., 2002 - Safflower. Dryland Cropping Systems, Oregon State University

AL-ALI A.S., AL-NEAMY K., ABBAS S.A., ABDUL-MASIH A.M., 1977 - On the life history of the safflower fly, Acanthiophilus helianthi Rossi (Dip., Tephritidae) in Iraq. -Zeitchr. Angew. Entomol. 83: 216-223.

ALIZADEH K., ESKANDARI M., SHARIATI A., ESKANDARI M., 2008 Study on spring type safflower lines suitable for cold drylands using GGE biplots. - World J. Agric. Sci. 4: 726-730.

AVIDOV Z., KOLTER E., 1966 - The pest of safflower Carthamus tinctorius $\mathrm{L}$. in Israel. In: AV/DOV, Studies in agricultural entomology and plant pathology. - Scripta Hier. Lym. Jerusalem 18 (cited in R.A.E. 54, 636).

BAGHERI M.R., 2006 - Study on the biology of safflower shoot fly and its damages in spring culture in Esfahan (Iran). - Agricultural and Natural Resources Research Center, Esfahan: 25 p.

BEZZI M., 1924 - Further notes on the Ethiopian fruit flies, with keys to all the known genera and species. - Bull. Entomol. Res. 15: 121-155.

BHADAURIA N.S., BHADOURIA N.K.S., JAKHMALA S.S., ASHOK S., 1999 - Succession and incidence of insect pests of safflower in north-west Medhyapradesh. - Bhar K. Anus. Patric. 14: 47-51.

BHATIA H.L., SINGH M., 1939 - Larvae of the Trypetidae. - Indian J. Entomol. 1: 107-114.

CAMPOBASSA G., OLONNELLI C., KNUTSON E., TERRAGITTI L., CRISTOFRO M., 1999 - Wild plants and their cited insects in the region, primarily Europe and the Middle East. - USDA-ARS, 147: $429 \mathrm{pp}$.

DIN I.M., GHANI M.A., 1963 - Preliminary study of the insects attacking

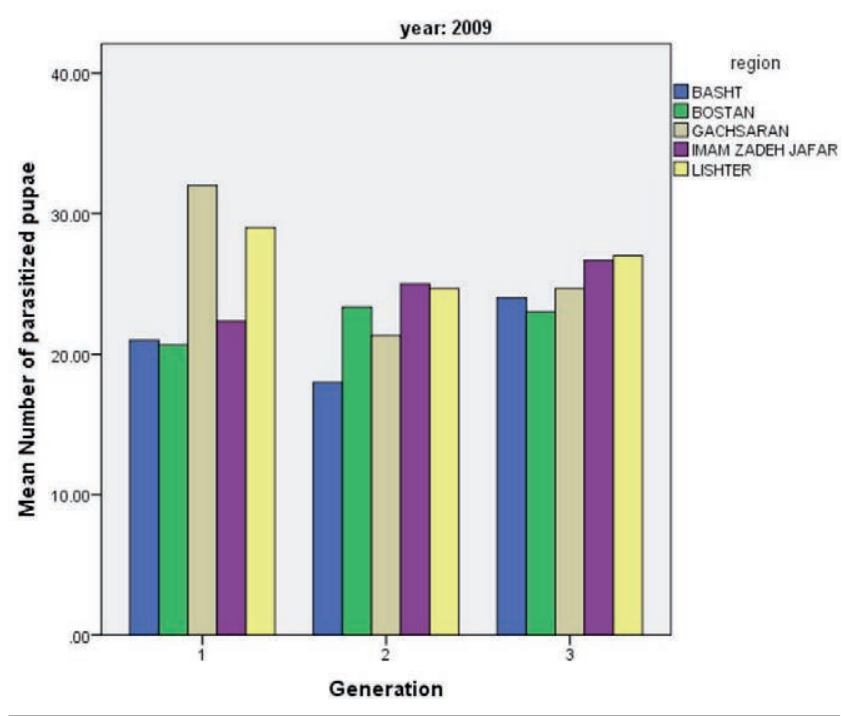

Figure 3. Percentage of parasitized pupae of Acanthiophilus helianthi in Kohgiluyeh safflower farms (2009).

Carthamus oxycantha (Compositae) in Pakistan. - Tech. Bull. Commonw. Inst. Biol. Cont. 3: 111-116.

EMONGOR V., 2010 - Safflower (Carthamus tinctorius L.) the underutilized and neglected crop: a review. - Asian J. Plant Sci. 9: 299-306.

GHARAEI B., JO0ZIAN E., 2001 - A report on the species Chaetorellia carthami Stackelberg, 1929. (Dep.: Tephrotidae) from Iran. Entomol. Soc. Iran. 21: 1010-1102.

GIRAY H., 1966 - Investigations on the species and the food plants of the family Trypetidae (fruit-flies) attacking cultivated plants in the Aegean region. - Ege. Univ. Zir. Fak. Yayn. N/126, VI + 61 PP. Izmir.

HEGAZI E.M., EL-CAYAR F.H., MOURSI K.S., EL-KADY Y.I., 1982 - On the role of capsule fly, Acanthiophilus helianthi Rossi (Dipt. Tephritidae) on the safflower plant, Carthamus tinctorius L. Egyptian Nat. Conf. Entom., Dec. 6-9th, Cario.

HEGAZI E.M., MOURSI K.S., 1983 - Studies on the distribution and biology of capsule fly, Acanthiophilus helianthi Rossi on wild plants in Egyptian western desert. - Z. Angew. Entomol. 96: 333-336.

JAKHMOLA S.S., YADAV H.S., 1980 - Incidence of and losses caused by capsule fly, Acanthiophilus helianthi Rossi in different varieties of safflower. - Indian J. Entomol. 42: 48-53.

KAP00R V.C., 2005 - Taxonomy and biology of economically important fruit flies of India. - Israel J. Entomol. 35: 459-475.

KEYHANIAN A.K., 2007 - Seasonal abundance of the safflower fly, Acanthiophilus helianthi Rossi (Diptera: Tephritidae), an infestation on safflower, Carthamus tinctorius L. in Ghom province, Iran. - Pajouhesh-va-Sazandegi 78: 57-62.

MAJIDI M.M., TAVAKOLI V., MIRLOHI A., SABZALIAN M.R., 2011 - Wild safflower species (Carthamus oxyacanthus Bieb.): A possible source of drought tolerance for arid environments. - Austr. J. Crop Sci. 5: 1055-1063.

MANOLACHE C., 1940 - Acanthiophilus helianthi Rossi. Viata Agric. 31, 65 Abstr. - Z. Pflkrankh. 52: 326.

MARTINOVICH V., 1966 - Acanthiophilus helianthi, a pest of Centaurea seed production in Hungary. - Folia. Entomol. Hung. 19: 375-402.

PRUTHI H.S., 1941 - Report of the imperial entomologist. - Sci. Rep. Agric. Res. Inst. New Delhi 1939-1940: 102-114. 
RADJABI G.R., 1991 - Harmful insects of fruit trees in Iran. - Iranian Research Institute of Plant Protection, Tehran: $221 \mathrm{pp}$.

RICCI C., CIRICIOFOLO E., 1983 - Observations on Acanthiophilus helianthi Rossi (Diptera: Tephritidae) injurious to safflower in central Italy. - Redia 66: 577-592.

SABZALIAN M.R., SAEIDI G., MIRLOHI A., HATAMI B., 2010 - Wild safflower species (Carthamus oxyacanthus): a possible source of resistance to the safflower flies (Acanthiophilus helianthi). - Crop Protection. 29: 550-555.

SWAILEM S.M., 1973 - On the binomics of Acanthiophilus helianthi Rossi. - Bull. Soc. Entomol. Egypt. 57: 165-172.

TALPUR M.A., HUSSAN T., RUSTAMANI M.A., GAAD A.M., 1995 -
Relative resistance of safflower varieties to safflower shootfly, Acanthiophilus helianthi Rossi (Diptera: Tephritidae). - Proc. Pakistan Congr. Zoology. 15: 177-181.

VAISHAMPAYAN S.M., KAPOOR K.N., 1970 - Note on assessment of losses to safflower (Carthamus tinctorius) by capsule fly, Acanthiophilus helianthi Rossi. - Indian J. Agric. Sci. 40:29-32.

VERMA A.N., SINGH R., MEHRATRA N., 1974 - Acanthiophilus helianthi Rossi. A serious pest of safflower in Haryana. - Indian J. Entomol. 34: 364-365.

ZANDIGIACOMO P., IOB M., 1992 - Acanthiophilus helianthi, Rossi (Diptera: Tephritidae) on safflower in Friuli. - Boll. Zool. Agr. Bachicolt. 23: 31-38. 